\title{
SOSIALISASI PERILAKU HIDUP BERSIH DAN SEHAT PADA ANAK-ANAK TINGKAT SEKOLAH DASAR DI DESA TABORE KECAMATAN MENTANGAI KALIMANTAN TENGAH
}

\author{
Rezqi Handayani ${ }^{1}$, Susi Novaryatiin ${ }^{1}$, Syahrida Dian Ardhany ${ }^{1}$ \\ 1DOSEN Program Studi D-III Farmasi, Fakultas IImu Kesehatan, Universitas Muhammadiyah \\ Palangkaraya, Palangka Raya, Kalimantan Tengah \\ Email: handayani.rahman@yahoo.co.id,
}

\begin{abstract}
ABSTRAK
Kesadaran akan pentingnya kebersihan dan kesehatan harus ditanamkan sejak dini. Membiasakan hidup bersih dan sehat dapat dilakukan oleh semua orang tidak terkecuali oleh anak-anak kecil. Membiasakan hidup bersih dan sehat dapat kita mulai dari hal-hal kecil seperti membiasakan untuk cuci tangan sebelum melakukan kegiatan terutama sebelum makan, membiasakan untuk menjaga kesehatan gigi dan mulut, membiasakan untuk selalu membuang sampah pada tempatnya, dan membiasakan untuk menjaga kebersihan di lingkungan rumah masing-masing. Dari hal-hal kecil tersebut kita dapat memulai untuk mewujudkan lingkungan yang bersih dan sehat sehingga dapat mewujudkan derajat kesehatan yang baik sehingga terhindar dari berbagai macam penyakit.

Sasaran dari pelaksanaan Pengabdian Kepada Masyarakat ini adalah anak-anak usia sekolah dasar yang ada di Desa Tabore Kecamatan Mentangai Kalimantan Tengah.Pelaksana dari kegiatan Pengabdian Kepada Masyarakat ini adalah dosen dan mahasiswa Program Studi D-III Farmasi Fakultas IImu Kesehatan Universitas Muhammadiyah Palangkaraya. Kegiatan yang dilakukan diantaranya penyampaian materi mengenai cara mencuci tangan dan sikat gigi yang baik dan benar. Pada materi disampaikan dampak atau penyakit yang akan diderita anak-anak bila tidak mencuci tangan dan sikat gigi mereka dengan baik dan benar. Pada saat penyampaian anak-anak diajak untuk terlibat langsung dalam mempraktekkan cara cuci tangan dan sikat gigi yang baik dan benar.

Kegiatan Pengabdian Kepada Masyarakat ini dapat dinyatakan berhasil karena adanya respons yang sangat baik dan antusiasme yang tinggi dari anak-anak dan warga Desa Tabore. Disadari pentingnya kegiatan ini dan dampak yang dapat ditimbulkan di masa depan, maka diharapkan kegiatan penyuluhan ini dapat dilanjutkan di desa-desa pedalaman lainnya apabila ada permintaan dari masyarakat dan kebutuhan di lapangan.
\end{abstract}

Kata Kunci: Hidup Bersih dan Sehat, Cuci Tangan, Sikat Gigi

\section{PENDAHULUAN}

Penyakit diare dan cacingan merupakan salah satu penyakit infeksi yang disebabkan oleh keberadaan mikroorganisme yang bersifat pathogen yaitu bakteri dan parasit. Penyakit infeksi berdasarkan data WHO merupakan salah satu penyakit terbesar yang menyebabkan kematian pada anak. Perkembangbiakan bakteri dan parasit sangat erat kaitannya dengan kebersihan lingkungan. Kedua mikroorganisme pathogen ini akan cepat berkembang biak pada lingkungan yang tidak bersih dan sehat. Golongan umur yang paling rentan menderita penyakit tersebut adalah anak-anak usia sekolah dasar karena daya tahan tubuhnya yang masih rendah. 
Berdasarkan Keputusan Menteri Kesehatan RI No. 1216/MenKes/SK/XI/2001 Tentang Pedoman Pemberantasan Penyakit Diare.. penyakit diare merupakan salah satu penyakit yang berbasis lingkungan, dua faktor yang sangat dominan adalah sarana air bersih dan pembuangan tinja. Kedua faktor ini akan berinteraksi bersama perilaku manusia, apabila faktor lingkungan yang tidak sehat karena tercemar bakteri atau virus, serta berakumulasi dengan perilaku manusia yang tidak sehat pula, maka dapat menimbulkan kejadian penyakit diare.

Menurut penelitian Nilton, et al (2008) faktor-faktor penyebab diare adalah menggunakan air sumur, minum air yang tidak dimasak, sumur $<10$ meter, tidak mempunyai jamban, tidak menggunakan jamban, tidak mempunyai tempat sampah dan tidak cuci tangan. Hasil Survei Kesehatan Rumah Tangga (SKRT) tahun 2004, menunjukkan angka kematian akibat diare adalah 23 per 100 ribu penduduk dan pada balita adalah 75 per 100 ribu balita. Berdasarkan Profil Kesehatan Indonesia Tahun 2006, angka kejadian diare nasional pada tahun 2006 sebesar 423 per seribu penduduk pada semua umur dan 16 provinsi mengalami Kejadian Luar Biasa (KLB) diare dengan Case Fatality Rate (CFR) sebesar 2,52 .

Penyakit cacingan adalah penyakit yang ditularkan melalui makanan minuman atau melalui kulit dimana tanah sebagai media penularannya yang disebabkan oleh cacing. Diseluruh dunia diperkirakan masih ditemukan sebanyak 300 juta kasus penyakit kecacingan, baik infestasi tunggal maupun infestasi campuran lebih dari satu jenis cacing diantaranya adalah cacing gelang (Ascaris lumbricoides), cacing cambuk (Trichuris trichuria), dan cacing tambang (Ancylostoma duodenale dan Necator americanus) (Dewayani, 2004). Laporan Hasil Survei Morbiditas Kecacingan Tahun 2005 Berdasarkan Laporan Hasil Survei Morbiditas Kecacingan Tahun 2005 ipenyakit nfeksi cacingan banyak terdapat pada anak usia sekolah dasar yaitu sekitar 40-60\%. Penyakit infeksi kecacingan ini masih merupakan problema kesehatan dan ekonomi yang utama pada masyarakat, pekerja maupun individu yang merugikan pertumbuhan dan kecerdasan anak.

Air sungai sebagai satu-satunya sumber air bersih juga digunakan oleh masyarakat desa Tabore untuk berkumur saat menyikat gigi. Hal ini berpotensi menyebabkan perkembangbiakan bakteri di dalam mulut, apabila tidak diimbangi dengan menjaga kebersihan gigi dan mulut.

Hasil Riset Kesehatan Dasar (RISKESDAS) 2013 di Kalimantan Tengah menunjukkan prevalensi anak yang mengalami masalah kesehatan gigi dan mulut berdasarkan karakteristik umur adalah 5-9 tahun sebesar 27,7\%, umur 10-14 tahun sebesar $25,3 \%$ dan terjadi di pedesaan sebesar $25,6 \%$. 
Dalam usaha menjaga kebersihan mulut faktor kesadaran dan perilaku pemeliharaan kebersihan gigi dan mulut personal. Hal ini begitu penting karena kegiatan yang dilakukan dirumah tanpa ada pengawasan dari siapapun, sepenuhnya tergantung dari pengetahuan, pemahaman, kesadaran serta kemauan dari pihak individu untuk menjaga kesehatan mulutnya. Untuk tujuan tersebut cara paling mudah dan umum dilakukan adalah dengan cara menyikat gigi secara teratur dan benar karena hal tersebut merupakan usaha yang dapat dilakukan secara personal.

Kelompok anak usia sekolah dasar merupakan kelompok yang rentan terhadap penyakit gigi dan mulut sehingga perlu diperhatikan dan dicegah secara baik dan benar. Sebanyak 25,3\% anak berusia 10-14 tahun yang memiliki masalah gigi dan mulut di Indonesia. Kondisi ini dapat berpengaruh pada derajat kesehatan mereka dalam proses tumbuh kembang bahkan masa depan mereka.

Pembersihan gigi yang kurang baik dapat menyebabkan terjadinya akumulasi plak. Salah satu cara menghilangkan plak yaitu dengan menyikat gigi. Plak adalah lapisan tipis, tidak berwarna, mengandung kumpulan bakteri, melekat pada permukaan gigi dan selalu terbentuk di dalam mulut dan bila bercampur dengan gula yang ada dalam makanan akan membentuk asam.
Kesadaran akan pentingnya kebersihan dan kesehatan harus ditanamkan sejak dini. Untuk merubah suatu keadaan menjadi lebih baik haruslah dimulai dari diri sendiri terlebih dahulu. Membiasakan hidup bersih dan sehat dapat dilakukan oleh semua orang tidak terkecuali oleh anak-anak kecil. Minimnya fasilitas memang mempunyai peran yang penting dalam mewujudkan hidup bersih dan sehat, tetapi bukan menjadi suatu hambatan untuk membuat masyarakat terbiasa untuk hidup bersih dan sehat. Mebiasakan hidup bersih dan sehat dapat kita mulai dari hal-hal kecil seperti membiasakan untuk cuci tangan sebelum melakukan kegiatan terutama sebelum makan, mebiasakan untuk menjaga kesehatan gigi dan mulut, membiasakan untuk selalu membuang sampah pada tempatnya, dan membiasakan untuk menjaga kebersihan di lingkungan rumah masing-masing. Dari hal-hal kecil tersebut kita dapat memulai untuk mewujudkan lingkungan yang bersih dans ehat sehingga dapat mewujudkan derajat kesehatan yang baik sehingga terhindar dari berbagai macam penyakit

Kondisi sehat dapat dicapai dengan mengubah perilaku dari yang tidak sehat menjadi Perilaku Hidup Bersih dan Sehat (PHBS) dan menciptakan lingkungan sehat di rumah tangga.. Oleh karena itu dalam pengabdian masyarakat ini sangat perlu sekali dilakukan sosialisasi tentang PHBS 
terutama pada anak-anak, dimana dalam hal ini yang menjadi fokus pengabdian adalah membentuk kebiasaan sikat gigi dengan benar dan mencuci tangan yang benar.

\section{LOKASI KEGIATAN}

Lokasi dilaksanakannya pengabdian masyarakat yaitu di Desa Tabore Kecamatan Mentangai Kalimantan Tengah. Lokasi ini sulit dijangkau karena letak Desa Tabore yang masih berada di pedalaman. Tetapi akses menuju kesana dipermudah dengan adanya jalan perusahaan sawit. Jarak dari kampus ke lokasi kegiatan \pm 50 $\mathrm{km}$ dan memerlukan waktu 2,5 jam untuk sampai di lokasi. Alat transportasi seperti motor dan mobil dapat memasuki area lokasi dan komunikasi disekitar lokasi juga lancar.

\section{METODE PELAKSANAAN}

Metode yang digunakan dalam kegiatan pengabdian adalah penyuluhan. Kegiatan dilakukan pada hari Minggu tanggal 20 Desember 2015. Kegiatan dimulai dari pukul 10.00-13.00 WIB. Kegiatan dilakukan di salah satu rumah warga yang diikuti oleh anak-anak usia sekolah dasar dan warga lainnya. Kegiatan dimulai dengan adanya pembukaan dari Kepala Desa Tabore yang kemudian dilanjutkan dengan perkenalan dan penyampaian materi oleh tim pelaksana. Dalam kegiatan dilakukan penyampaian materi yang menggunakan power point, penanyangan video tentang cuci tangan dan sikat gigi yang baik dan benar.

\section{HASIL DAN PEMBAHASAN}

Sasaran dari pelaksanaan Pengabdian Masyarakat yang berjudul "Sosialisasi Perilaku Hidup Bersih dan Sehat pada Anak-Anak Tingkat Sekolah Dasar di Desa Tabore Kecamatan Mentangai Kalimantan Tengah" adalah anak-anak usia sekolah dasar yang ada di Desa Tabore Kecamatan Mentangai Kalimantan Tengah.

Desa Tabore merupakan salah satu desa yang terletak di Kecamatan Mentangai Kalimantan Tengah, bila dibandingkan dengan desa lain yang ada di Kalimantan Tengah, Desa Tabore merupakan salah satu desa tertinggal. Desa ini belum mendapatkan pasokan listrik dan mempunyai sistem sanitasi yang tidak baik. Pasokan listrik hanya diperoleh malam hari dan menggunakan genset dalam pengoperasiannya. Sedangkan sanitasi masyarakat Desa Tabore hanya mengandalkan air sungai sebagai satusatunya sumber air bersih. Tidak ada pasokan air bersih yang diterima oleh masyarakat Desa Tabore. Oleh karena itu tingkat derajat kesehatan Desa Tabore masih rendah, hal ini terbukti dengan seringnya masyarakat Desa Tabore khususnya anak kecil yang menderita penyakit diare dan cacingan.

Materi yang disampaikan dalam kegiatan ini adalah mengenai cara cuci 
tangan dan sikat gigi yang baik dan benar. Pada materi disampaikan dampak atau penyakit yang akan diderita anak-anak bila tidak mencuci tangan dan sikat gigi dengan baik dan benar. Pada saat penyampaian anak-anak diajak untuk terlibat langsung dalam mempraktekkan cara cuci tangan dan sikat gigi yang baik dan benar.

Pada saat penyampaian materi, anak-anak juga diajak untuk melihat penayangan video yang menceritakan tentang efek yang ditimbulkan apabila tidak mencuci tangan setelah bermain dan tidak menyikat gigi setelah makan. Anak-anak terlihat antusias dalam melihat video tersebut karena pemberian informasi disampaikan dalam bentuk animasi 3dimensi yaitu kartun.

Setelah penyampaian materi dilakukan sesi diskusi atau tanya jawab. Pada sesi ini anak-anak diminta untuk maju ke depan untuk mempraktekkan cara mencuci tangan dan sikat gigi yang baik dan benar. Pemberian doorprize diberikan kepada peserta yang dapat berani maju ke depan dan mempraktekkannya secara langsung. Selain pemberian doorprize sebagai salah bentuk penghargaan dan ucapan terimakasih dari tim pelaksana terhadap peserta kegiatan, masing-masing anak yang ikut dalam pengabdian diberikan satu buah sikat gigi dan pasta gigi serta sabun cuci tangan. Diharapkan dengan pemberian ini anak-anak dapat mempraktekkannya secara langsung di kehidupan sehari-sehari mereka.

Kegiatan Pengabdian Kepada Masyarakat mengenai "Sosialisasi Perilaku Hidup Bersih dan Sehat pada Anak-Anak Tingkat Sekolah Dasar di Desa Tabore Kecamatan Mentangai Kalimantan Tengah" yang dilakukan oleh Tim Dosen Program Studi D-III Farmasi ini sangat bermanfaat. Kegiatan ini dapat memberikan tambahantambahan informasi mengenai Perilaku Hidup Bersih dan Sehat terutama dalam hal cuci tangan dan sikat gigi. Dengan adanya kegiatan ini anak-anak diharapkan mampu mengaplikasikan materi yang didapat di kehidupan sehari-hari.

\section{KESIMPULAN}

Kegiatan Pengabdian Kepada Masyarakat ini dapat dinyatakan berhasil karena adanya respons yang sangat baik dan antusiasme yang tinggi dari anak-anak dan warga Desa Tabore dalam mengikuti kegiatan ini, serta dapat terlaksananya kegiatan sesuai dengan jadwal yang telah ditentukan.

\section{DAFTAR PUSTAKA}

1. Badan Penelitian dan Pengembangan Kesehatan Kementerian Kesehatan RI. 2013. Riset Kesehatan Dasar (Riskesdas) 2013 Provinsi Kalimantan Tengah. Jakarta. 
2. Departemen Kesehatan Republik Indonesia. 2005a. Laporan Hasil Survei Morbiditas Kecacingan Tahun 2005. Subdit Diare dan Penyakit Pencernaan Ditjen PPM \& PLP. Depkes RI. Jakarta.

3. Departemen Kesehatan Republik Indonesia. 2005b. Keputusan Menteri Kesehatan RI 1216/MenKes/SK/XI/2001 Tentang

Pedoman Pemberantasan Penyakit Diare. Ditjen PPM \& PLP. Depkes RI. Jakarta.

4. Departemen Kesehatan Republik Indonesia. 2005. Hasil Survey Kesehatan Rumah Tangga (SKRT) Tahun 2004. Jakarta.
5. Departemen Kesehatan Republik Indonesia. 2006. Profil Kesehatan Indonesia 2006. Jakarta.

6. Nilton, dkk. 2008. Faktor-Faktor Sanitasi yang Berpengaruh Terhadap Timbulnya Penyakit Diare di Desa Klopo Sepuluh Kecamatan Sukodono Kabupaten Sidoarjo. Laporan Penelitian Mahasiswa IImu Kesehatan Masyarakat Fakultas Kedokteran Universitas Uniwijaya Kusuma. Surabaya. 